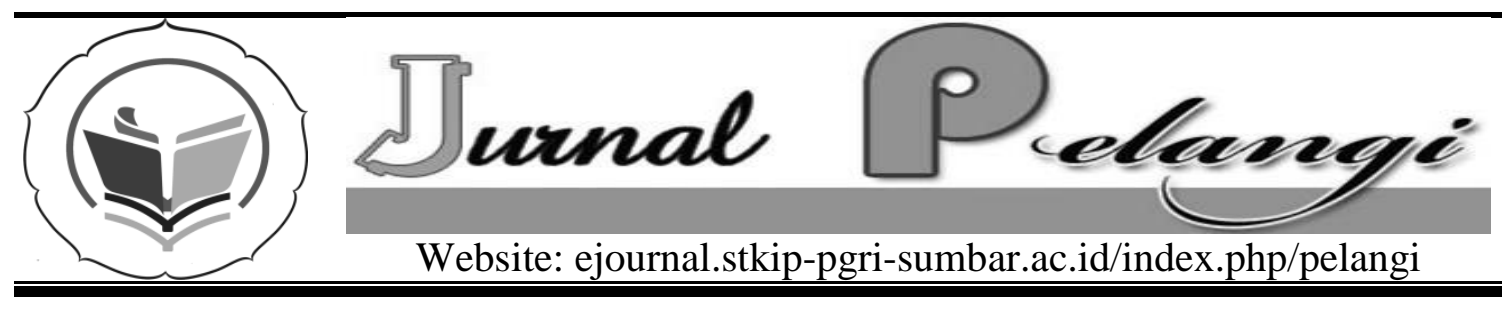

\title{
PENGEMBANGAN MEDIA INTERAKTIF BERBASIS KARAKTER PADA MATERI SISTEM PEREDARAN DARAH MANUSIA UNTUK SMA
}

\author{
Febri Yanti ${ }^{1 *}$, Fifi Yasmi ${ }^{2)}$ dan Jaenam ${ }^{3)}$ \\ STKIP PGRI Sumbar \\ * Febriyanti1985@yahoo.co.id,
}

INFO ARTIKEL

Diterima: 01-01-2014

Disetujui: 01-12-2014

Kata Kunci:

Pengembangan,

Interaktif,

Karakter,

PeredaranDarah
Abstrak

Guru masih sedikit menggunakan strategi pada proses pembelajaran. Pada umumnya, guru lebih sering mengajar dengan mempresentasikan materi menggunakan media pada proses pembelajaran tanpa mempertimbangkan penilaian karakter. Penggunaan media pada pembelajaran bertujuan untuk meningkatkan kreativitas, ketertarikan dan motivasi belajar. Keuntungan media pembelajaran interaktif adalah dapat memotivasi siswa agar belajar sendiri, kreatif, efektif dan efisien. Media ini bertujuan untuk digunakan oleh guru biologi pada beberapa sekolah. Penelitian ini merupakan penelitian pengembangan. Model dan prosedur pengembangan menggunakan 4-D (four-D-model), terdiri dari define, design, develop dan dessiminate. Tahapan dessiminate tidak dilakukan. Data dikumpulkan dengan melakukan validasi dan uji coba media. Media divalidasi oleh dosen ahli biologi Indonesia dan guru biologi SMA. Uji coba dilakukan pada siswa kelas XI IPA SMA 2 Padang untuk menilai praktikalitas media interaktif. Hasil validasi yang dilakukan oleh 3 orang validator memperlihatkan bahwa media interaktif ini sangat valid dengan nilai 90,69\%. Hasil praktikalitas 3 orang guru biologi dan siswa sekolah memperlihatkan bahwa media interaktif ini sangat praktis dengan tingkat kepraktisan 90,55\% dan 86,07\%. Dari hasil kedua kriteria penilaian ini dapat disimpulkan bahwa media yang dikembangkan bermanfaat pada proses pembelajaran, baik untuk guru maupun untuk siswa 


\section{Abstract}

Keywords:

Development

Interactive

character

\section{PENDAHULUAN}

Pendidikan adalah usaha sadar dan terencana untuk mewujudkan suasana belajar dan proses pembelajaran agar siswa secara aktif mengembangkan potensi dirinya, melalui pembelajaran berbasis spritual, agama, pengendalian diri, kepribadian, kecerdasan, akhlak mulia, dan keterampilan yang diperlukan bagi dirinya, masyarakat, bangsa dan negara (UUSPN, 2003). Dalam hal ini pendidikan memegang peranan yang sangat penting bagi kelangsungan kehidupan manusia. Bangsa yang maju selalu diawali dengan kesuksesan pendidikan, sebab lembaga pendidikan sebagai tempat mencetak sumber daya manusia berkualitas dan menjadi motor kemajuan dan kemakmuran bangsa.

Pada kenyataan di lapangan berdasarkan wawancara peneliti dengan guru-guru yang terlibat dalam pembelajaran biologi di SMA kelas XI kota Padang bahwa masih 
rendahnya pemahaman siswa dalam memahami materi biologi dikarenakan dalam proses pembelajaran guru kurang bervariasi dalam menggunakan strategi pembelajaran karena guru lebih sering berceramah dalam menyampaikan materi dan jarang menggunakan media dalam proses pembelajaran. Selain itu peneliti juga melihat banyaknya siswa SMA yang terlibat tauran dan perbuatan asusila lainnya, ini disebabkan karena pendidikan karakter di sekolah tidak diterapkan hanya mengutamakan materi pelajaran tanpa memanamkan nilai karakter.

Informasi yang diberikan oleh beberapa guru biologi SMA di kota Padang menyatakan kepada peneliti bahwa media yang pernah digunakan guru dalam pembelajaran yaitu media power point. Siswa kurang memahami dan kurang menarik dalam proses pembelajaran. Maka dari itu peneliti ingin meneliti dan mengembangkan proses pembelajaran biologi dengan komputer sebagai media yang digunakan yang berpola tutorial interaktif. Dalam bentuk bahan ajar dan disusun secara sistematis disertai dengan animasianimasi yang menarik dan dibuat dengan software makromedia flash serta dikemas dalam bentuk media interaktif yang bisa digunakan di sekolah maupun belajar mandiri di rumah.

Manfaat media pembelajaran interaktif ini diharapkan akan memotivasisiswa untuk belajar mandiri, kreatif, efektif dan efisien. Selain itu dengan mediapembelajaran interaktif ini, diharapkan dapat mengurangi kejenuhan siswa karenaselama ini proses pembelajaran yang dilakukan oleh kebanyakan sekolah adalahmetode ceramah, diskusi dan tanya jawab.

Dari uraian di atas, maka penulis ingin melakukan penelitian dengan judul “ Pengembangan media Compact Disc (CD) Interaktif berbasis karakter pada materi pembelajaran sistem peredaran darah manusia untuk SMA “

\section{METODE PENELITIAN}

Jenis penelitian yang dilakukan adalah penelitian pengembangan. Penelitian pengembangan merupakan suatu proses ataulangkah-langkah untuk mengembangkan suatu produk baru atau menyempurnakan produk yang telah ada yang dapat dipertanggung jawabkan.

Subjek penelitian ini adalah media interaktif untuk mengetahui sistem peredaran darah pada manusia yang akan dipelajari di SMA serta untuk mengetahui validitas dan praktikalitas media.

Prosedur penelitian pengembangan media interaktif ini menggunakan model pengembangan 4-D (four D). Model ini dikembangkan oleh S.Thigarajan, Dorothy S. Semmel dan Melvyn I. Semmel (1974) dalam Trianto (2010:94). Model pengembangan 4-D 
terdiri atas 4 tahap utama yaitu : Define (pendefenisian), Design (perancangan),

Develop

(pengembangan) dan Dessiminate (penyebaran).

Dalam penelitian ini penulis hanya melakukan sampai tahap develop.

a. Tahap define ( pendefenisian )

Tahap define bertujuan menentukan masalah dasar yang dibutuhkan dalam mengembangkan media pembelajaran biologi sehingga dapat menjadi alternatif media pembelajaran yang sesuai.

Adapun langkah-langkah yang dilakukan dalam tahap ini adalah :

1. Analisa terhadap kurikulum tingkat satuan pendidikan (KTSP)

2. Menelaah standar kompetensi dan kompetensi dasar yang harus dimiliki siswa setelah mempelajari materi sistem peredaran darah manusia.

3. Menelaah indicator-indikator

4. Analisa media

5. Analisa siswa

b. Tahap design ( perancangan )

Pada tahap ini yang akan dilakukana dalah merancang Prototip media pembelajaran, media interaktif yang dirancang khusus untuk materi sistem peredaran darah di SMA.

Setelah media dirancang, makalangkah selanjutnya adalah membuat media interaktif dengan menggunakan computer.

c. Tahap develop ( pengembangan )

Tahap ini bertujuan untuk menghasilkan produk yang sudah direvisi berdasarkan masukan dari validator. Pada tahap ini dilakukan uji validitas dan praktikalitas.

Instrument yang digunakan untuk pengumpulan data dalam penelitian ini adalah :

1. Lembar validitas

Lembar validasi digunakan untuk memperoleh data tentang tingkat validitas media pembelajaran yang dikembangkan bila digunakan dalam pelajaran biologi.

2. Angket

Angket digunakan untuk memperoleh data tentang tingkat praktikalitas media pembelajaran yang dikembangkan. Angket ini diberikan kepada guru dansiswa.

Teknik analisis yang digunakan adalah deskriptif yang mendeskripsikan validitas dan kepraktisan.

1. Analisis validitas media interaktif Analisis validitas media interaktif berupa materi, bentuk media, motivasi media dan bahasa, berdasarkan angket validasi dilakukan dengan beberapa langkah berikut ini.

a. Memberikan skor jawaban dengan kriteria yang berdasarkan skala Likert dalam Arikunto (2008) sebagai berikut ini:

$4=$ sangat setuju

$3=$ setuju

2 = tidak setuju

$1=$ sangat tidak setuju.

b. Menentukan skor tertinggi 
Skor tertinggi $=$ jumlah validator $\mathrm{x}$ jumlah indikator $\mathrm{x}$ skor maksimum.

c. Menentukan jumlah skor dari masing-masing validator dengan menjumlahkan semua skor yang diperoleh dari masing-masing indikator.

d. Menentukan skor yang diperoleh dengan menjumlahkan skor dari masing-masing validator.

e. Penentuan nilai validitas dengan cara berikut ini.

Nilai validitas

$=\frac{\text { jumlah skor yang diperoleh }}{\text { jumlah skor tertinggi }} \times 100 \%$

f. Memberikan penilaian validitas dengan kriteria yang dimodifikasi dari Purwanto (2009) berikut ini: $90-100 \%=$ sangat valid $80-89 \%=$ valid $65-79 \%=$ cukup valid $55-64 \%=$ kurang valid $<55 \%=$ tidak valid

2. Analisapraktikalitas media interaktif

Data uji praktikalitas media interaktif dianalisis dengan rumus:

Nilai praktikalitas $=$

Jumlah skor yang diperoleh Skor maksimal X 100\%

Memberikan penilaian praktikalitas dengan kriteria:

$0-54 \%=$ Sangat tidak praktis

$55-59 \%=$ Kurang praktis

$60-75 \%=$ Cukup praktis

$76-85 \%=$ Praktis

$86-100 \%=$ Sangat Praktis
Dimodifikasi dari Purwanto (2009).

\section{HASIL DAN PEMBAHASAN}

Pengembangan media interaktif berbasis karakter untuk SMA ini mengunakan model 4-D. Untuk mendapatkan media yang valid, dilakukan beberapa tahap sesuai dengan model 4-D. Hasil yang diperoleh pada masing-masing tahapan dapat diuraikan sebagai berikut.

\section{Pendefinisian (define)}

Tahap ini dilakukan untuk melihat gambaran kondisi di lapangan yang berkaitan dengan proses pembelajaran Biologi SMA. Pada tahap ini dilakukan langkah-langkah seperti analisis silabus. Analisis media yang ada, analisis karakteristik siswa dan wawancara dengan guru SMA. Hasil yang diperoleh pada masing-masing langkah tersebut adalah sebagai berikut.

\section{a. Analisis Silabus}

Pada tahap ini dilakukan analisis terhadap silabus mata pelajaran Biologi SMA. Analisis silabus dilakukan untuk melihat apakah materi yang diajarkan sudah sesuai dengan kompetensi yang diharapkan.

Berdasarkan hasil dari analisis silabus diketahui bahwa Standar Kompetensi (SK) dari mata pelajaran Biolosi SMA kelas XI Semester I yang sulit untuk di jelaskan oleh guru adalah Menjelaskan struktur dan fungsi organ manusia dan hewan tertentu, kelainan/penyakityang mungkin terjadi serta implikasinya 
padaSalingtemas,

selanjutnya,

Kompetensi Dasar (KD) yang diharapkan adalah Menjelaskan keterkaitan antara struktur, fungsi, dan proses serta kelainan yang dapat terjadi pada sistem peredaran darah. Selanjutnya dikembangkan indikatornya yaitu 1). Menjelaskan hubungan antara berbagai komponen darah dan fungsinya, 2). Membuat skema proses pembekuan darah, 3). Menjelaskan hubungan stuktur pembuluh darah dan fungsinya, 4). Menjelaskan hubungan bagian-bagian jantung dan fungsinya, 5). Menggambarkan lintasan peredaran darah pada manusia, 6). Mendeskripsikan gangguan/penyakit yang terjadi pada sistem peredaran darah manusia.

\section{b. Analisis Media}

Analisis media yang dilakukan bertujuan untuk melihat apakah isi media sudah sesuai dengan Kompetensi dalam silabus. Media yang dianalisis adalah media yang sering di pakai oleh guru dalam mengajar. Berdasarkan analisis yang telah dilakukan diperoleh hasil bahwa media yang banyak beredar dan yang sering digunakan oleh guru-guru di sekolah banyak yang tidak sesuai dengan SK dan KD yang ada dan materi yang disajikan belum lengkap dan jelas. Penyajian materi pada media yang beredar pada umumnya masih banyak menggunakan bahasa Inggris dan belum mampu melibatkan siswa secara aktif dalam membangun pemahaman konsep dan sikap siswa.

\section{c. Analisis Karakteristik Siswa}

Berdasarkan hasil pengamatan dan pendataan yang telah dilakukan, diketahui bahwa, dilihat dari tingkatan umur siswa yang berusia dari 15-18 tahun, maka siswa sudah mampu memperoleh strategi yang logis, rasional dan abstrak serta anak mulai mandiri secara ekonomi, menerima tanggung jawab tingkah lakunya, mandiri dalam mengambil keputusan, mampu menentukan sikap yang didasari pertimbangan keyakinan yang dijadikan filsafat hidup dan mampu membina hubungan dengan orang tua dan sesama.

d. Wawancara dengan guru SMA

Setelah menganalisis media, kegiatan selanjutnya adalah wawancara dengan beberapa guru Biologi SMA. Wawancara dengan guru ini bertujuan untuk mengetahui masalah/hambatan apa saja yang dihadapi di lapangan sehubungan dengan pembelajaran Biologi SMA.

Berdasarkan hasil wawancara, diketahui bahwa selama ini proses pembelajaran Biologi hanya mengacu pada buku teks dan sering menggunakan metode ceramah, jarang sekali guru menggunakan media. Siswa banyak bergantung pada penjelasan guru dalam memahami konsep materi. Ini berarti, siswa belum mampu untuk balajar mandiri. Oleh karena itu, diperlukan suatu media yang praktis dari guru dengan metode pengembangan tertentu sehingga mampu 
memfasilitasi siswa untuk belajar secara mandiri dan memiliki karakter.

\section{Perancangan (design)}

Pada tahap ini telah disusun kerangka dan format media pembelajaran interaktif berkarakter melalui beberapa tahapan yaitu:

a. Merancang halaman-halaman pada media $C D$ interaktif di atas kertas berupa storyboard dengan urutan;

1) Tampilan pembuka

Berisitayangan tentang: judul media, gambar,tampilan ini dimaksudkan menjelaskan secara umum materi apa yang akan dibahas.

2) Pengantar

Pada tampilan pengantar memuat tentang: kompetensi, materi, latihan, kesimpulan dan penutup. Pemilihan tampilan ini memudahkan para penggunan media khususnya siswa memilih bagian yang dibahas pada media $C D$ interaktif.

3) Kompetensi

Tampilan ini memuat tentang: standar kompetensi, kompetensi dasar, indikator dan tujuan. Pemilihan tampilan pada kompetensi bertujuan agar siswamengetahuistandarkomp etensi, kompetensi dasar, indicator dan tujuan yang akan dicapai setelah melakukan pembelajaran dengan
menggunakan $C D$ interaktif.

4) Uraianmateri

Berisi tampilan tentang materi sistem peredaran darah manusia yang dibutuhkan siswa untuk membentuk penguasaan kemampuan sesuai dengan tujuan pembelajaran. Materi yang akan dibahas diantaranya: Fungsi sistem peredaran darah, komponen penyusunan darah, proses pembekuan darah, pembuluh darah, struktur dan fungsi jantung, mekanisme peredaran darah, dan gangguan sistem peredaran darah. Tampilan materi dilengkapi dengan gambar, animasi, suara dan musik. Tujuan pembuatan animasi ini, agar siswabisa melihat sendiri bagaimana proses yang sistem peredaran darah manusia yang terjadi.

5) Latihan

Pada menu latihan berisi beberapa soal dengan jumlah 4 butir pilihan jawaban dan dilengkapi dengan kunci jawaban. Pada akhir jawaban akan ditentukan skor yang diperoleh berdasarkan banyaknya soal yang benar. Tujuan diberikan soal latihan untuk mengetahui kemampuan diri mereka sendiri apakah sudah memahami materi yang sedang dipelajrai. 
6) Kesimpulan

Menu kesimpulan disusun dalam bentuk kata-kata dan iringi dengan musik.

7) Penutup

Menu penutup berisikan tentang nama tim peneliti, programmer, program dan literature yang dipakai. Pemilihanisi pada penutup bertujuan agar segala sesuatu yang berhubungan dengan perancangan $C D$ interaktif, dapat dikemukakan secara jelas.

b. Merancang gambar-gambar animasi yang lengkap dengan keterangan dan penjelasan tiap gambar, yang dibuat dengan menggunankan program software macromedia flash professional 8 untuk memuat animasi gambardan software music editor free sebagai editan suara.

c. Mengisi suara atau music pada lembar-lembar tertentu, sesuai dengan kebutuhan materi/isi pada $C D$ interaktif.

d. Langkah terakhir dalam perancangan (Design) adalah burning kedalam Compact Disc $(C D)$.

Langkah-langkah dalam mendesain media interaktif dapat dilihat pada lampiran 2. Tahapan ini perlu dimasukkan untuk membantu guru dan siswa bila $C D$ interaktif ini tidak bisa dibuka tampilannya, maka guru dan siswa dapat menginstal program ini terlebih dahulu ke laptop atau komputernya dengan menggunakan program instal yang telah disediakan kedalam media $C D$ interaktif ini.

\section{Pengembangan (develop)}

\section{Uji kevalidan oleh beberapa validator}

Data yang penulis deskripsikan adalah data yang diperoleh dari hasil validasi oleh pakar terhadap media interaktif yang berjumlah 3 orang dengan 4 aspek validasi.

Data tersebut kemudian diolah sehingga diperoleh skor rata-rata kevalidan media ini seperti terlihat pada Tabel 1.

Tabel 1. Hasil Validasi Media Interaktif

\begin{tabular}{|l|c|c|c|c|}
\hline No & Aspek yang & Skor & Nilaivalidasi & Kriteria \\
& divalidasi & validator & $(\%)$ & \\
\hline
\end{tabular}




\begin{tabular}{|l|l|l|l|l|c|c|}
\hline & & I & II & III & & \\
\hline 1 & Bentuk media & 35 & & & 87,50 & Valid \\
\hline 2 & Motivasi & 31 & & & 96,88 & Sangat Valid \\
\hline 3 & Materi Rata-rata & & 39 & 41 & 90,90 & Sangat Valid \\
\hline 4 & Bahasa & & 13 & 15 & 87,50 & Valid \\
\hline & \multicolumn{2}{|c|}{ Sangat Valid } \\
\hline
\end{tabular}

Keterangan: Validator I memvalidasi bentuk media dan motivasi media

Validator II memvalidasi materi dan bahasa

Validator III memvalidasi materi dan bahasa

Berdasarkan hasil penilaian validator yang terlihat pada Tabel 1 menunjukan bahwa media interaktif telah mengacu kepada kategori sangat valid dengan nilai rata-rata 90,69\%. Angka yang diperoleh menunjukan media ini dapat digunakan setelah ada perubahan atau revisi yang dilakukan sesuai saran yang diberikan validator.

\section{Uji Praktikalitas oleh Guru}

Uji kepraktisan media interaktif yang dibuat, dianalisa oleh guru biologi yang mengajar di kelas XI IPA SMA. Berdasarkan pengisian angket kepraktisan media interaktif diperoleh data seperti yang terdapat pada Tabel 2.

Tabel2. Kepraktisan Media Interaktif Oleh Guru

\begin{tabular}{|l|c|c|c|l|}
\hline Aspek yang dinilai & Item & $\begin{array}{c}\text { Penilaian3 } \\
\text { orang guru }\end{array}$ & $\begin{array}{c}\text { Nilai } \\
\text { praktikalit } \\
\text { as (\%) }\end{array}$ & Kriteria \\
\hline $\begin{array}{l}\text { 1. Kemudahan dalam } \\
\text { penggunaan }\end{array}$ & $1-5$ & 55 & 91,67 & Sangatpraktis \\
\hline 2. Waktu Pelaksanaan & $6-7$ & 21 & 87,5 & Sangatpraktis \\
\hline $\begin{array}{c}\text { 3. Daya Tarik } \\
\text { Perangkat }\end{array}$ & $8-10$ & 34 & 94,45 & Sangatpraktis \\
\hline $\begin{array}{c}\text { 4. Interprestasikan } \\
\text { materi }\end{array}$ & 11 & 10 & 83,33 & praktis \\
\hline $\begin{array}{c}\text { 5.Ekivalen yang sama } \\
\text { dengan bahan ajar }\end{array}$ & $12-$ & 23 & 95,83 & Sangat praktis \\
\hline \multicolumn{2}{|l|}{ Rata-rata } & & 90,55 & Sangatpraktis \\
\hline
\end{tabular}


Dari Tabel 2 dapat dilihat secara umum kriteria penilaian uji praktikalitas oleh 3 orang guru biologi terhadap media interaktif adalah sangat praktis. Berdasarkan kriteria tersebut maka media interaktif yang dihasil dapat digunakan pada proses pembelajaran, baik dari segi manfaat yang didapat, mudahan dalam penggunaan, kesesuaian dengan waktu dan evaluasi yang digunakan.

\section{Uji praktikalitas oleh siswa}

Respon siswa terhadap media interaktif pada materi sistem klasifikasi makhluk hidup dapat di lihat pada Tabel

Tabel3. Kepraktisan Media Interaktif Oleh Siswa

90,90\%. Aspek konstruk/bentuk media

\begin{tabular}{|l|c|c|l|}
\hline \multicolumn{1}{|c|}{ Aspek yang dinilai } & Item & $\begin{array}{c}\text { Nilaipraktikalit } \\
\text { as (\%) }\end{array}$ & \multicolumn{1}{|c|}{ Kriteria } \\
\hline $\begin{array}{l}\text { 1. Kemudahan dalam } \\
\text { penggunaan }\end{array}$ & $1-6$ & 81,83 & Praktis \\
\hline 2. Ketersediaan Waktu & $7-9$ & 86 & Sangat praktis \\
\hline 3. Daya Tarik Perangkat & $10-11$ & 89,5 & Sangat praktis \\
\hline 4. Interprestasikan materi & 12 & 87 & Sangat praktis \\
\hline $\begin{array}{l}\text { 5. Ekivalen yang sama } \\
\text { dengan bahan ajar }\end{array}$ & 13 & 86 & Sangatpraktis \\
\hline Rata-rata & & 86,07 & Sangat praktis \\
\hline
\end{tabular}

Berdasarkan data praktikalitas media interaktif yang didapat dari siswa seperti terlihat pada Tabel 3, dapat diketahui bahwa dari aspek yang dinilai secara umum respon siswa terhadap media interaktif yang digunakan adalah positif, dengan kriteria sangat praktis. Siswa merasa tertarik dan berminat belajar menggunakan media interaktif ini karena tampilan media interaktif yang menarik, mudah digunakan dan jelas.

Berdasarkan uji validitas yang dilakukan, pada aspek materi memiliki kriteria sangat valid dengan nilai validasi memiliki kriteria valid dengan nilai validasi $87,5 \%$ dan aspek motivasi pada media memiliki kriteria sangat valid dengan nilai validasi $96,88 \%$. Tetapi tidak terlepas dari revisi yang disarankan oleh validator. Dimana revisi yang dilakukan adalah bagian suara pada beranda, standar kompetensi, kompetensi dasar dan indikator. Selain itu revisi juga dilakukan pada bagian gambar yang ada di dalam materi supaya lebih menarik perhatian siswa. Hal ini sejalan dengan pendapat Rusman (2011) bahwa manfaat 
media pembelajaran dalam proses pembelajaran adalah pembelajaran akan

lebih menarik perhatian siswa sehingga dapat menumbuhkan motivasi belajar, materi pembelajaran akan lebih jelas maknanya sehingga dapat lebih dipahami oleh para siswa dan memungkinkan siswa menguasai tujuan pembelajaran lebih baik.

Hasil praktikalitas yang diberikan kepada 3 orang guru biologi dan satu kelas siswa terhadap media interaktif yang dihasilkan menunjukkan media interaktif sangat praktis. Pada uji praktikalitas ini diamati beberapa aspek, diantaranya aspek kemudahan dalam penggunaan dengan penilaina $91,67 \%$ dan $81,83 \%$, aspek waktu yang diperlukan dalam pelaksanaan dengan penilaian $87,50 \%$ dan $86 \%$, daya tarik perangkat terhadap minat siswa dengan penilaian $94,45 \%$ dan $89,50 \%$, aspek kemudahan dalam mengiterpretasikan materi dengan penilaian $83,33 \%$ dan $87 \%$, aspek memiliki ekivalen yang sama dengan bahan ajar yang digunakan dengan penilaian $95,83 \%$ dan $86 \%$.

Dari hasil penilaian kedua kriteria tersebut menyatakan bahwa media yang peneliti kembangkan bermanfaat dalam proses pembelajaran, baik untuk guru maupun untuk siswa. Manfaat yang didapat untuk guru yaitu dapat mengurangi penggunaan papan tulis oleh guru dalam penyampaian materi. Guru juga terbantu bila harus mengulang kembali materi, karena siswa dapat memutarnya kembali di rumah sesuai dengan kemampuannya menangkap materi pelajaran tersebut. Sedangkan manfaat yang diperoleh untuk siswa yaitu siswa menjadi lebih aktif dan berminat dalam mengikuti pelajaran karena siswa tidak lagi hanya menerima materi dari guru, tetapi siswa diminta lebih aktif. Jadi dengan meningkatkan keaktifan dan minat siswa dalam mengikuti pelajaran, maka secara tidak langsung pelajaran akan menjadi lebih menarik dan mudah menangkap materi pelajaran yang akan diberikan.

\section{KESIMPULAN}

Berdasarkan hasil analisis data maka dapat disimpulkan, media interaktif berkarakter pada materi sistem peredaran darah manusia untuk SMA yang dikembangkan sudah sangat valid dan sangat praktis untuk bisa digunakan dan dimanfaatkan dalam proses belajar mengajar.

\section{UCAPAN TERIMA KASIH}

Penelitian ini terselenggara atas bantuan dari DP2M Dikti dan kerjasama dengan stakeholders yang telah memberikan tempat pelaksanaan penelitian.

\section{DAFTAR PUSTAKA}

Arikunto, Suharsimi. 2008. Dasar-dasar Evaluasi Pendidikan. Jakarta: Bumi Aksara.

Purwanto, Ngalim. M. 2009. Prinsipprinsip dan Teknik Evaluasi Pengajaran. Bandung: Remaja Rosdakarya.

Rusman, K dan Riyana, C. 2011. Pembelajaran Berbasis Teknologi Informasi Komunikasi. Jakarta: Rajawali Pers.

Trianto. 2010. Model Pembelajaran Terpadu. Jakarta.: Bumi Aksara.Undang-Undang RI. No. 20 Tahun 2003 tentang Sistem Pendidikan Nasional. 2003. Jakarta : Departemen Pendidikan Nasional 